\title{
The Excretion of Acid in Unilateral Renal Disease in Man*
}

\author{
Philip R. Steinmetz, $\nmid$ Robert P. Eisinger, $\$$ and Jerome Lowenstein $\S$ \\ (From the Department of Medicine, Nere York University School of Medicine, and the Third \\ and Fourth Medical Divisions, Bellevue Hospital, Nerw York, N. Y.)
}

In chronic forms of renal disease the capacity to excrete acid, and in particular ammonia, is reduced (1-5). The mechanisms involved in this reduction, however, are not well understood. The excretion of acid might be decreased by a specific tubular defect in the secretion of hydrogen ions or the formation of ammonia or alternatively by total loss of function in groups of nephrons with normal tubular function in the remaining nephrons. Since the excretion of hydrogen ions is influenced to a considerable extent by extrarenal factors, it is difficult to make comparisons between normal subjects and patients with renal disease, who often have alterations in systemic acid-base equilibrium, solute load, and salt excretion. To overcome such limitations, Morrin, Bricker, Kime, and Klein (6) employed an experimental model of unilateral disease in the dog that allowed examination of the diseased kidney in the same milieu as the normal kidney. In man, except for a few observations in renal arterial stenosis $(7-10)$, the acidifying capacity of the diseased kidney has not been studied in a comparable way.

The present investigation was undertaken to examine the mechanism of acid excretion in forms of human renal disease confined to one kidney or involving one kidney to a greater extent than the other. Patients with predominantly

\footnotetext{
* Submitted for publication March 9, 1964; accepted December 10, 1964.

Supported by U. S. Public Health Service grant HE 03272 from the National Heart Institute.

$\dagger$ Recipient of U. S. Public Health Service Career Development Award 1-K3-HE-12,113-01. Address requests for reprints to: Dr. Philip R. Steinmetz, New York University School of Medicine, 550 First Avenue, New York, N. Y. 10016.

¥ Senior research fellow, New York Heart Association; presently Clinical Investigator, Manhattan Veterans Administration Hospital, New York, N. Y.

§ Postdoctoral research fellow, U. S. Public Health Service.
}

unilateral pyelonephritis, renal infarction, and other forms of renal vascular disease were studied comparing the diseased with the "normal" kidney.

The excretion of ammonium and titratable acid by the diseased kidney was found to be proportional to the size of the functioning nephron mass, and urine $\mathrm{pH}$ was the same in the diseased and normal kidneys. This general relationship was preserved following ammonium chloride loading. In patients with renal arterial stenosis, however, the affected kidney tended to elaborate a more acid urine than its mate.

\section{Methods}

Observations were made on 12 patients with predominantly unilateral renal disease selected from the wards of the New York University Medical Services of Bellevue Hospital. Eight had disease of the renal parenchyma (group I), and four had stenosis of one main renal artery (group II). To provide control observations on acid excretion in the separate kidneys in the presence of symmetric impairment of function, data are presented for three additional patients with diffuse bilateral renal disease, either chronic glomerulonephritis or nephrosclerosis (group III). In group I, pyelonephritis was present in three patients, renal infarction in one, renal atrophy in two, and hypoplastic kidneys with decreased function in two patients. In group II, three patients had atherosclerosis and one fibromuscular hyperplasia of the main renal artery. Brief case reports are given in the Appendix. None of the patients had azotemia or metabolic acidosis.

All patients ate a regular diet. Three patients of group I were studied a second time following ammonium chloride loading. Ammonium chloride was given in gelatin capsules in a daily dose of $8 \mathrm{~g}$ for 4 days before study. All studies were carried out on fasting patients after a 12-hour period of fluid deprivation. To maintain a similar antidiuretic state in all patients, $5 U$ of aqueous vasopressin ${ }^{1}$ was administered intramuscularly before urine collections and $200 \mathrm{mU}$ per hour intravenously with the sustaining infusion of inulin and paraaminohippurate. Most subjects also received an infusion of either $15 \%$ urea in $5 \%$ dextrose solution or $10 \%$ mannitol at rates varying between 1.7 and $4.0 \mathrm{ml}$ per

1 Pitressin, Parke, Davis, Detroit, Mich. 

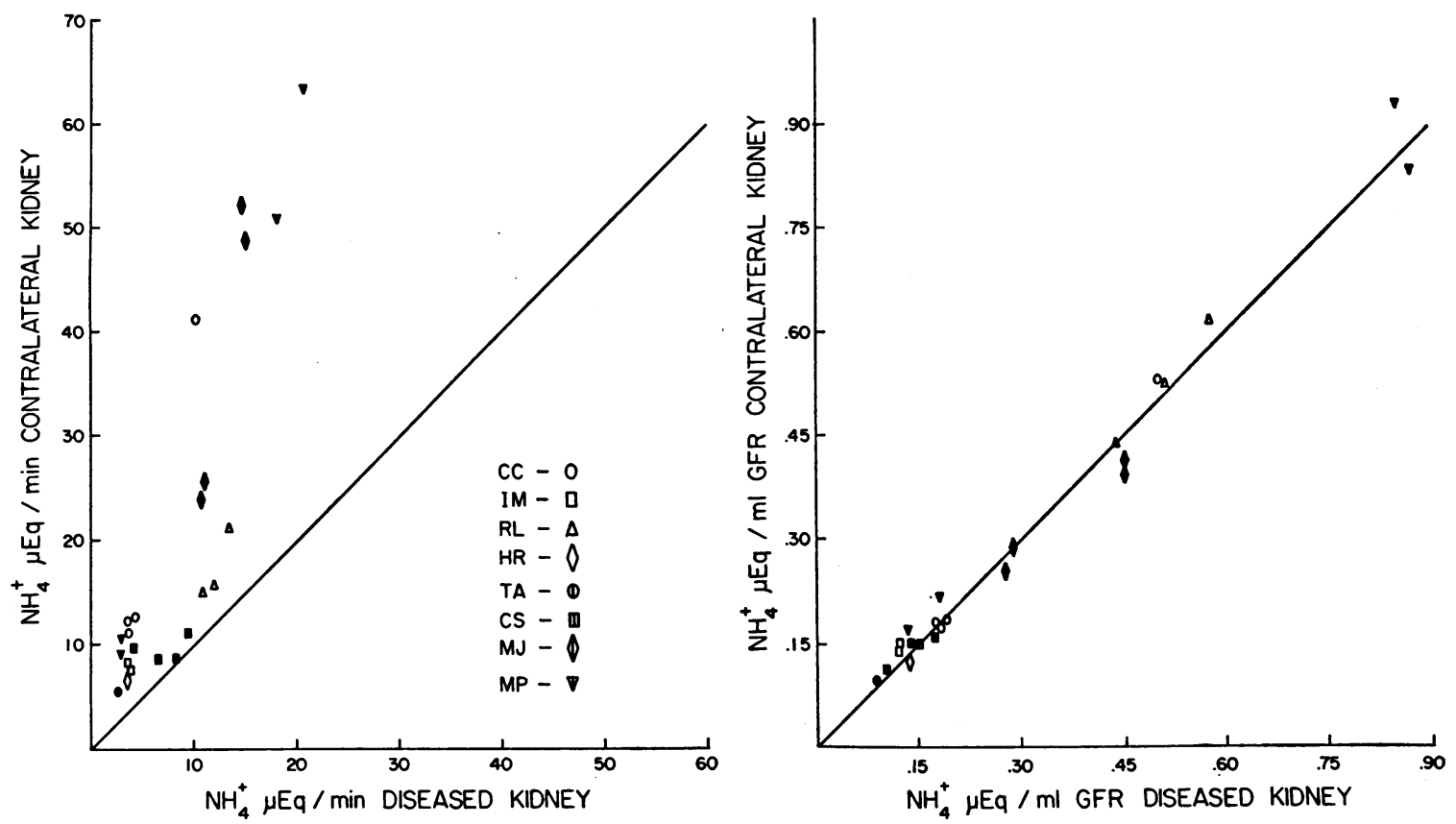

Fig. 1. COMParison OF AMMONIUM EXCRETION IN THE TWO RIDNEYS OF EIGHT PATIENTS WITH UNILATERAL RENAL DISEASE. In the frame on the left are plotted total excretion rates and in the frame on the right excretion rates per unit of glomerular filtration rate (GFR).

minute to ensure a satisfactory urine flow. The subjects assumed the recumbent position about 1 hour before study and remained recumbent during study. Urine was collected from the separate kidneys according to previously described techniques (11). The ureteral catheters were allowed to drain directly into graduated cylinders containing mineral oil. Determinations of inulin, para-aminohippurate, osmolality, sodium, potas-

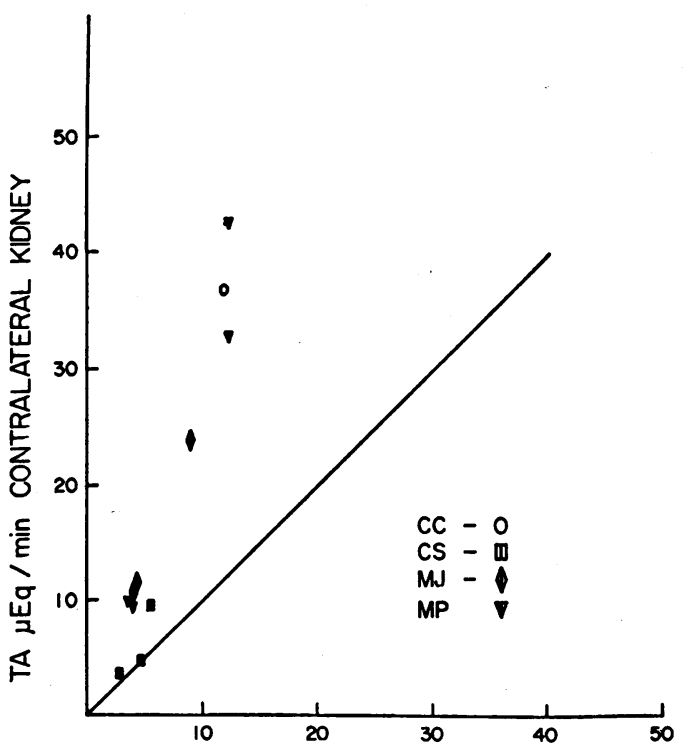

TA $\mu \mathrm{Eq} / \min$ DISEASED KIDNEY

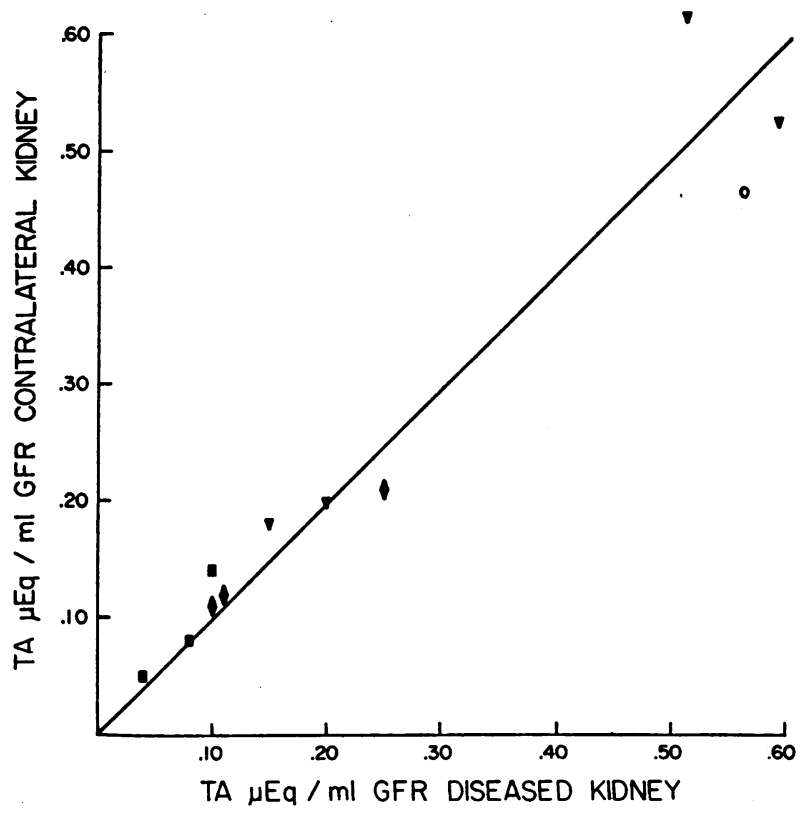

TA $\mu E q / m l$ GFR DISEASED KIDNEY

Fig. 2. COMPARISON OF TA EXCRETION IN THE TWO KIDNEYS OF FOUR PATIENTS WITH UNILATERAL RENAL DISEASE. In the frame on the left are plotted total excretion rates and in the frame on the right excretion rates per unit of GFR. 
TABLE I

Urine $p H$ and renal acid excretion in patients with

\begin{tabular}{|c|c|c|c|c|c|c|c|c|c|c|}
\hline \multirow[b]{2}{*}{ Patient } & \multicolumn{2}{|c|}{$\mathrm{V}$} & \multicolumn{2}{|c|}{$\mathrm{C}_{\text {In }} \dagger$} & \multicolumn{2}{|c|}{$\mathrm{C}_{\mathrm{PAH}}$} & \multicolumn{2}{|c|}{$\mathrm{UNaV}_{\mathrm{Na}}$} & \multicolumn{2}{|c|}{$\mathrm{UKV}_{\mathrm{K}}$} \\
\hline & $\mathrm{D}$ & C & $\mathrm{D}$ & $\bar{c}$ & D & C & D & C & D & $\bar{c}$ \\
\hline & \multicolumn{2}{|c|}{$m l / \min$} & \multicolumn{2}{|c|}{$m l / m i n$} & \multicolumn{2}{|c|}{$\mathrm{ml} / \mathrm{min}$} & \multicolumn{2}{|c|}{$\mu E q / \min$} & \multicolumn{2}{|c|}{$\mu E q / \min$} \\
\hline C.C. & $\begin{array}{l}2.4 \\
2.7 \\
3.1\end{array}$ & $\begin{array}{l}6.2 \\
7.5 \\
8.1\end{array}$ & $\begin{array}{l}20 \\
21 \\
22\end{array}$ & $\begin{array}{l}67 \\
69 \\
71\end{array}$ & $\begin{array}{l}73 \\
78 \\
76\end{array}$ & $\begin{array}{l}240 \\
254 \\
245\end{array}$ & $\begin{array}{l}276 \\
308 \\
350\end{array}$ & $\begin{array}{l}771 \\
912 \\
954\end{array}$ & $\begin{array}{l}38 \\
38 \\
44\end{array}$ & $\begin{array}{l}112 \\
120 \\
130\end{array}$ \\
\hline I.M. & $\begin{array}{l}0.79 \\
1.2 \\
1.8\end{array}$ & $\begin{array}{l}1.1 \\
1.2 \\
2.0\end{array}$ & $\begin{array}{l}28 \\
32 \\
30\end{array}$ & $\begin{array}{l}57 \\
52 \\
64\end{array}$ & $\begin{array}{l}106 \\
131 \\
121\end{array}$ & $\begin{array}{l}209 \\
199 \\
254\end{array}$ & $\begin{array}{l}160 \\
243 \\
413\end{array}$ & $\begin{array}{l}209 \\
243 \\
483\end{array}$ & $\begin{array}{l}38 \\
49 \\
55\end{array}$ & $\begin{array}{l}68 \\
68 \\
97\end{array}$ \\
\hline R.L. & $\begin{array}{l}0.42 \\
0.52 \\
0.58\end{array}$ & $\begin{array}{l}0.58 \\
0.68 \\
0.84\end{array}$ & $\begin{array}{l}25 \\
24 \\
24\end{array}$ & $\begin{array}{l}34 \\
30 \\
34\end{array}$ & $\begin{array}{l}110 \\
112 \\
112\end{array}$ & $\begin{array}{l}138 \\
139 \\
167\end{array}$ & $\begin{array}{l}48 \\
53 \\
61\end{array}$ & $\begin{array}{r}688 \\
72 \\
81\end{array}$ & $\begin{array}{l}17 \\
18 \\
18\end{array}$ & $\begin{array}{l}24 \\
27 \\
30\end{array}$ \\
\hline H.R. & 0.86 & 1.9 & 26 & 56 & 119 & 252 & 209 & 492 & 42 & 100 \\
\hline T.A. & 0.97 & 1.3 & 33 & 60 & 113 & 212 & 171 & 202 & 33 & 71 \\
\hline C.S. & $\begin{array}{l}1.4 \\
2.0 \\
2.5\end{array}$ & $\begin{array}{l}2.3 \\
2.6 \\
3.6\end{array}$ & $\begin{array}{l}63 \\
59 \\
55\end{array}$ & $\begin{array}{l}79 \\
61 \\
68\end{array}$ & $\begin{array}{l}226 \\
242 \\
223\end{array}$ & $\begin{array}{l}323 \\
262 \\
284\end{array}$ & $\begin{array}{l}351 \\
541 \\
672\end{array}$ & $\begin{array}{l}563 \\
686 \\
940\end{array}$ & $\begin{array}{r}88 \\
99 \\
103\end{array}$ & $\begin{array}{l}134 \\
120 \\
146\end{array}$ \\
\hline M.J. & $\begin{array}{l}1.5 \\
2.1\end{array}$ & $\begin{array}{l}2.4 \\
3.5\end{array}$ & $\begin{array}{l}40 \\
38\end{array}$ & $\begin{array}{l}99 \\
90\end{array}$ & $\begin{array}{l}173 \\
132\end{array}$ & $\begin{array}{l}348 \\
284\end{array}$ & $\begin{array}{l}142 \\
155\end{array}$ & $\begin{array}{l}232 \\
278\end{array}$ & $\begin{array}{l}18 \\
17\end{array}$ & $\begin{array}{l}39 \\
42\end{array}$ \\
\hline M.P. & $\begin{array}{l}1.7 \\
1.1\end{array}$ & $\begin{array}{l}3.7 \\
3.2\end{array}$ & $\begin{array}{l}23 \\
19\end{array}$ & $\begin{array}{l}56 \\
48\end{array}$ & $\begin{array}{r}104 \\
74\end{array}$ & $\begin{array}{l}249 \\
199\end{array}$ & $\begin{array}{l}240 \\
164\end{array}$ & $\begin{array}{l}478 \\
417\end{array}$ & $\begin{array}{l}27 \\
29\end{array}$ & $\begin{array}{l}75 \\
64\end{array}$ \\
\hline \multicolumn{11}{|c|}{ Studies following $\mathrm{NH}_{4} \mathrm{Cl}$ loading } \\
\hline C.C. $\ddagger$ & 0.29 & 1.1 & 21 & 78 & & & 40 & 154 & 18 & 69 \\
\hline M.J. & $\begin{array}{l}1.8 \\
2.1\end{array}$ & $\begin{array}{l}2.8 \\
3.6\end{array}$ & $\begin{array}{l}33 \\
33\end{array}$ & $\begin{array}{l}129 \\
116\end{array}$ & $\begin{array}{l}106 \\
108\end{array}$ & $\begin{array}{l}394 \\
358\end{array}$ & $\begin{array}{l}192 \\
228\end{array}$ & $\begin{array}{l}256 \\
336\end{array}$ & $\begin{array}{l}28 \\
30\end{array}$ & $\begin{array}{l}74 \\
72\end{array}$ \\
\hline M.P. & $\begin{array}{l}1.2 \\
1.9\end{array}$ & $\begin{array}{l}2.4 \\
3.5\end{array}$ & $\begin{array}{l}21 \\
24\end{array}$ & $\begin{array}{l}61 \\
69\end{array}$ & $\begin{array}{l}87 \\
94\end{array}$ & $\begin{array}{l}290 \\
294\end{array}$ & $\begin{array}{l}190 \\
286\end{array}$ & $\begin{array}{l}334 \\
436\end{array}$ & $\begin{array}{l}29 \\
34\end{array}$ & $\begin{array}{l}76 \\
97\end{array}$ \\
\hline
\end{tabular}

$* \mathrm{~V}=$ urine flow; $\mathrm{C}_{\mathrm{In}}$ and $\mathrm{C}_{\mathrm{PAH}}=$ clearance of inulin and para-aminohippurate; $\mathrm{U}_{\mathrm{Na}} \mathrm{V}, \mathrm{U}_{\mathrm{K}} \mathrm{V}, \mathrm{U}_{\mathrm{NH}} \mathrm{V}$, and $\mathrm{U}_{\mathrm{TA}} \mathrm{V}=$ excretion of sodium, potassium, ammonium, and titratable acid; $\mathrm{EF}_{\mathrm{Na}}=$ excreted fraction of filtered sodium; $\mathrm{D}=$ diseased kidney; $\mathrm{C}=$ contralateral kidney. Three significant figures were utilized for calculation of derived data.

$\dagger C_{I n}$ was taken as an estimate of functional nephron mass.

$\mp \mathrm{C}_{\text {creatinine }}$ used instead of $\mathrm{C}_{\mathrm{In}}$.

sium, $\mathrm{pH}$, ammonium, and titratable acid (TA) were performed as previously described $(11,12)$. Glomerular filtration rate (GFR) was determined by the inulin clearance $\left(\mathrm{C}_{\mathrm{In}}\right)$ and effective renal plasma flow by the paraaminohippurate clearance $\left(\mathrm{C}_{\mathbf{P A B}}\right)$. The excreted fraction of filtered sodium $\left(\mathrm{EF}_{\mathrm{Na}}\right)$ was calculated as previously reported (11). All clearances and excretion rates were expressed for a surface area of $1.73 \mathrm{~m}^{2}$.

\section{Results}

Acid excretion in the separate kidneys of patients with predominantly unilateral renal disease (group I). In Table I values for urine $\mathrm{pH}$, ammonium, and titratable acid excretion are compared in the diseased and contralateral kidneys of eight patients with predominantly unilateral parenchymal disease. $\mathrm{C}_{\mathrm{In}}$ and $\mathrm{C}_{\mathrm{PAH}}$ were significantly decreased in the diseased kidney, whereas values for the contralateral kidney were within the normal range for all patients except R.L. In three of the patients a second study was carried out after ammonium chloride loading (lower section of Table I).

The $\mathrm{pH}$ of the urine from the diseased and the normal kidneys was approximately the same in nine of the 11 studies; in the first study of M.J. and the second study of M.P. urine $\mathrm{pH}$ was from 0.4 to $0.7 \mathrm{U}$ higher in the diseased kidney.

Ammonium excretion was decreased in the diseased kidney in all studies and TA excretion in all those in which it was measured. When expressed per unit of GFR, however, ammonium and TA excretion were closely comparable in the two kidneys. This is further demonstrated in Figures 1 and 2. Following ammonium chloride 
TABLE I

predominantly unilateral decreases in functional nephron mass*

\begin{tabular}{|c|c|c|c|c|c|c|c|c|c|c|c|}
\hline \multicolumn{2}{|c|}{$\mathrm{EF}_{\mathrm{Na}}$} & \multicolumn{2}{|c|}{$\mathrm{pH}$} & \multicolumn{2}{|c|}{$\mathrm{UNH}_{4} \mathrm{~V}$} & \multicolumn{2}{|c|}{$\mathrm{UNH}_{4} \mathrm{~V} / \mathrm{C}_{\mathrm{In}}$} & \multicolumn{2}{|c|}{ UTAV } & \multicolumn{2}{|c|}{$\mathrm{U}_{T A} \mathrm{~V} / \mathrm{C}_{\mathrm{In}}$} \\
\hline $\mathrm{D}$ & $\bar{C}$ & $\mathrm{D}$ & $\bar{C}$ & $\mathrm{D}$ & $\mathrm{C}$ & $\mathrm{D}$ & $\mathrm{C}$ & $\mathrm{D}$ & $\mathrm{C}$ & $\mathrm{D}$ & $\mathrm{C}$ \\
\hline \multicolumn{2}{|c|}{$\%$} & & & \multicolumn{2}{|c|}{$\mu E q / \min$} & & & \multicolumn{2}{|c|}{$\mu E q / \min$} & & \\
\hline $\begin{array}{r}9.3 \\
10.1 \\
11.0\end{array}$ & $\begin{array}{l}7.8 \\
9.0 \\
9.2\end{array}$ & $\begin{array}{l}7.2 \\
7.2 \\
7.2\end{array}$ & $\begin{array}{l}7.2 \\
7.2 \\
7.3\end{array}$ & $\begin{array}{l}3.7 \\
3.6 \\
4.1\end{array}$ & $\begin{array}{l}11.1 \\
12.3 \\
12.8\end{array}$ & $\begin{array}{l}0.18 \\
0.17 \\
0.19\end{array}$ & $\begin{array}{l}0.17 \\
0.18 \\
0.18\end{array}$ & & & & \\
\hline $\begin{array}{l}4.1 \\
5.4 \\
9.8\end{array}$ & $\begin{array}{l}2.6 \\
3.3 \\
5.3\end{array}$ & $\begin{array}{l}7.1 \\
7.2 \\
7.2\end{array}$ & $\begin{array}{l}6.8 \\
7.0 \\
7.1\end{array}$ & $\begin{array}{l}3.3 \\
3.9 \\
4.3\end{array}$ & $\begin{array}{l}8.2 \\
7.7 \\
9.9\end{array}$ & $\begin{array}{l}0.12 \\
0.12 \\
0.15\end{array}$ & $\begin{array}{l}0.14 \\
0.15 \\
0.15\end{array}$ & & & & \\
\hline $\begin{array}{l}1.3 \\
1.5 \\
1.8\end{array}$ & $\begin{array}{l}1.4 \\
1.7 \\
1.7\end{array}$ & $\begin{array}{l}5.6 \\
5.5 \\
5.5\end{array}$ & $\begin{array}{l}5.8 \\
5.7 \\
5.6\end{array}$ & $\begin{array}{l}11.0 \\
12.2 \\
13.9\end{array}$ & $\begin{array}{l}15.0 \\
15.7 \\
21.2\end{array}$ & $\begin{array}{l}0.44 \\
0.51 \\
0.58\end{array}$ & $\begin{array}{l}0.44 \\
0.52 \\
0.62\end{array}$ & & & & \\
\hline 5.4 & 6.0 & 6.6 & 6.5 & 3.7 & 7.4 & 0.14 & 0.13 & & & & \\
\hline 3.7 & 2.3 & 6.9 & 6.9 & 2.7 & 5.4 & 0.08 & 0.09 & & & & \\
\hline $\begin{array}{l}3.9 \\
6.5 \\
8.4\end{array}$ & $\begin{array}{l}5.0 \\
7.8 \\
9.6\end{array}$ & $\begin{array}{l}7.0 \\
6.7 \\
6.7\end{array}$ & $\begin{array}{l}7.0 \\
6.8 \\
6.8\end{array}$ & $\begin{array}{l}6.7 \\
8.4 \\
9.5\end{array}$ & $\begin{array}{r}8.7 \\
8.9 \\
11.0\end{array}$ & $\begin{array}{l}0.09 \\
0.14 \\
0.17\end{array}$ & $\begin{array}{l}0.11 \\
0.15 \\
0.16\end{array}$ & $\begin{array}{l}2.8 \\
4.6 \\
5.4\end{array}$ & $\begin{array}{l}3.7 \\
4.7 \\
9.5\end{array}$ & $\begin{array}{l}0.04 \\
0.08 \\
0.10\end{array}$ & $\begin{array}{l}0.05 \\
0.08 \\
0.14\end{array}$ \\
\hline $\begin{array}{l}2.0 \\
2.8\end{array}$ & $\begin{array}{l}1.6 \\
2.2\end{array}$ & $\begin{array}{l}6.6 \\
6.4\end{array}$ & $\begin{array}{l}5.9 \\
6.0\end{array}$ & $\begin{array}{l}10.7 \\
11.2\end{array}$ & $\begin{array}{l}24.2 \\
25.8\end{array}$ & $\begin{array}{l}0.28 \\
0.29\end{array}$ & $\begin{array}{l}0.24 \\
0.29\end{array}$ & $\begin{array}{l}3.8 \\
4.2\end{array}$ & $\begin{array}{l}10.9 \\
11.3\end{array}$ & $\begin{array}{l}0.10 \\
0.11\end{array}$ & $\begin{array}{l}0.11 \\
0.12\end{array}$ \\
\hline $\begin{array}{l}7.6 \\
6.2\end{array}$ & $\begin{array}{l}6.1 \\
6.2\end{array}$ & $\begin{array}{l}6.8 \\
6.5\end{array}$ & $\begin{array}{l}6.6 \\
6.4\end{array}$ & $\begin{array}{l}3.1 \\
3.4\end{array}$ & $\begin{array}{r}9.6 \\
10.7\end{array}$ & $\begin{array}{l}0.13 \\
0.18\end{array}$ & $\begin{array}{l}0.17 \\
0.22\end{array}$ & $\begin{array}{l}3.4 \\
3.8\end{array}$ & $\begin{array}{r}10.0 \\
9.6\end{array}$ & $\begin{array}{l}0.15 \\
0.20\end{array}$ & $\begin{array}{l}0.18 \\
0.20\end{array}$ \\
\hline \multicolumn{12}{|c|}{ Studies following $\mathrm{NH}_{4} \mathrm{Cl}$ loading } \\
\hline 1.4 & 1.3 & 5.0 & 4.8 & 10.5 & 41.2 & 0.50 & 0.53 & 11.9 & 36.8 & 0.56 & 0.47 \\
\hline $\begin{array}{l}4.3 \\
5.1\end{array}$ & $\begin{array}{l}1.5 \\
2.2\end{array}$ & $\begin{array}{l}5.0 \\
5.0\end{array}$ & $\begin{array}{l}4.8 \\
4.8\end{array}$ & $\begin{array}{l}14.9 \\
15.1\end{array}$ & $\begin{array}{l}52.5 \\
49.1\end{array}$ & $\begin{array}{l}0.45 \\
0.46\end{array}$ & $\begin{array}{l}0.41 \\
0.42\end{array}$ & 8.4 & 23.9 & 0.25 & 0.21 \\
\hline $\begin{array}{l}6.9 \\
9.0\end{array}$ & $\begin{array}{l}4.1 \\
4.8\end{array}$ & $\begin{array}{l}5.2 \\
5.4\end{array}$ & $\begin{array}{l}4.8 \\
4.9\end{array}$ & $\begin{array}{l}18.0 \\
20.4\end{array}$ & $\begin{array}{l}50.9 \\
63.9\end{array}$ & $\begin{array}{l}0.87 \\
0.85\end{array}$ & $\begin{array}{l}0.87 \\
0.93\end{array}$ & $\begin{array}{l}12.3 \\
12.2\end{array}$ & $\begin{array}{l}32.8 \\
42.6\end{array}$ & $\begin{array}{l}0.59 \\
0.51\end{array}$ & $\begin{array}{l}0.53 \\
0.62\end{array}$ \\
\hline
\end{tabular}

loading, at higher levels of ammonium and TA excretion, the excretion rates per unit of GFR were again the same in the diseased and the normal kidneys.

The per cent of $\mathrm{EF}_{\mathrm{Na}}$ was somewhat greater in the diseased kidney in six of the 11 studies. In these studies there was also a greater urine flow per unit of GFR (not tabulated). Despite these differences the excretion of ammonium and TA was approximately proportional to GFR. In two of these studies a slightly higher $\mathrm{pH}$ was observed in the urine from the diseased kidney in association with a higher excretion of sodium and water per unit of GFR.

Potassium excretion was decreased in the dis- eased kidney in proportion to the decrease in GFR.

Acid excretion in the separate kidneys of patients with unilateral renal arterial stenosis (group $I I)$. In Table II, data are presented for four patients with unilateral renal arterial stenosis and decreased excretion of sodium and water in the affected kidney. In two of the patients $C_{\text {In }}$ and $\mathrm{C}_{\mathbf{P A B}}$ were in the normal range in the contralateral kidney; in the other two there was bilateral decrease in function. In all four, urine $\mathrm{pH}$ was lower in the kidney with the greater sodium reabsorption. Marked differences in urine $\mathrm{pH}$ were observed in H.J. and G.B. and smaller differences in C.R. and M.C. In H.J. ammonium and TA excretion were increased per unit of GFR in the 
TABLE II

Urine $p H$ and renal acid excretion in patients with unilateral renal

\begin{tabular}{|c|c|c|c|c|c|c|c|c|c|c|}
\hline \multirow[b]{2}{*}{ Patient } & \multicolumn{2}{|c|}{$\mathrm{V}$} & \multicolumn{2}{|c|}{$\mathrm{C}_{\text {In }}$} & \multicolumn{2}{|c|}{$\mathrm{C}_{\mathrm{PAH}}$} & \multicolumn{2}{|c|}{$\mathrm{U}_{\mathrm{NaV}}$} & \multicolumn{2}{|c|}{ UKV } \\
\hline & D & $\mathrm{C}$ & $\mathrm{D}$ & $\mathrm{C}$ & $\mathrm{D}$ & $\mathrm{C}$ & D & $\bar{C}$ & $\mathrm{D}$ & $\bar{c}$ \\
\hline & \multicolumn{2}{|c|}{$m l / \min$} & \multicolumn{2}{|c|}{$m l / \min$} & \multicolumn{2}{|c|}{$m l / \min$} & \multicolumn{2}{|c|}{$\mu E q / \min$} & \multicolumn{2}{|c|}{$\mu E q / \min$} \\
\hline H.J. & $\begin{array}{l}0.46 \\
0.55 \\
0.62\end{array}$ & $\begin{array}{l}0.64 \\
0.70 \\
0.80\end{array}$ & $\begin{array}{l}32 \\
33 \\
28\end{array}$ & $\begin{array}{l}32 \\
32 \\
28\end{array}$ & $\begin{array}{l}117 \\
121 \\
123\end{array}$ & $\begin{array}{l}106 \\
119 \\
126\end{array}$ & $\begin{array}{r}8 \\
12 \\
15\end{array}$ & $\begin{array}{l}16 \\
18 \\
24\end{array}$ & $\begin{array}{l}24 \\
23 \\
25\end{array}$ & $\begin{array}{l}34 \\
29 \\
30\end{array}$ \\
\hline G.B.† & $\begin{array}{l}0.40 \\
1.1 \\
2.5\end{array}$ & $\begin{array}{l}15.8 \\
18.5 \\
21.0\end{array}$ & 42 & 99 & $\begin{array}{l}166 \\
274\end{array}$ & $\begin{array}{l}355 \\
306\end{array}$ & $\begin{array}{r}77 \\
298 \\
610\end{array}$ & $\begin{array}{l}2,391 \\
2,808 \\
3,230\end{array}$ & $\begin{array}{r}45 \\
94 \\
160\end{array}$ & $\begin{array}{l}245 \\
185 \\
210\end{array}$ \\
\hline C.R. & $\begin{array}{l}1.2 \\
1.8 \\
1.6\end{array}$ & $\begin{array}{l}1.5 \\
2.8 \\
2.9\end{array}$ & $\begin{array}{l}32 \\
48 \\
39\end{array}$ & $\begin{array}{l}47 \\
66 \\
56\end{array}$ & $\begin{array}{l}112 \\
164 \\
136\end{array}$ & $\begin{array}{l}149 \\
204 \\
171\end{array}$ & $\begin{array}{l}61 \\
75 \\
57\end{array}$ & $\begin{array}{l}130 \\
248 \\
263\end{array}$ & $\begin{array}{l}31 \\
46 \\
35\end{array}$ & $\begin{array}{l}48 \\
79 \\
76\end{array}$ \\
\hline M.C. & $\begin{array}{l}0.55 \\
0.75\end{array}$ & $\begin{array}{l}0.80 \\
1.1\end{array}$ & $\begin{array}{l}20 \\
21\end{array}$ & $\begin{array}{l}29 \\
25\end{array}$ & $\begin{array}{l}80 \\
69\end{array}$ & $\begin{array}{r}110 \\
78\end{array}$ & $\begin{array}{l}47 \\
68\end{array}$ & $\begin{array}{r}77 \\
108\end{array}$ & $\begin{array}{l}22 \\
23\end{array}$ & $\begin{array}{l}32 \\
32\end{array}$ \\
\hline
\end{tabular}

* See Table I for abbreviations. Three significant figures were utilized for calculation of derived data.

† Observations were made during sodium sulfate diuresis. The excretion of bicarbonate in the contralateral kidney ranged from 201 to $217 \mu$ Eq per minute, whereas bicarbonate was absent from the urine of the affected kidney. $\mathrm{C}_{I_{n}}$ was determined in a separate study during water diuresis without solute loading. In this study $\mathrm{EF}_{\mathrm{Na}}$ was $0.2 \%$ in $\mathrm{D}$ and $5 \%$ in $\mathrm{C}$.

antinatriuretic kidney; during sodium sulfate diuresis this disparity in acid excretion between the two kidneys was markedly increased. In this patient the contralateral kidney excreted large quantities of bicarbonate (see footnote of Table

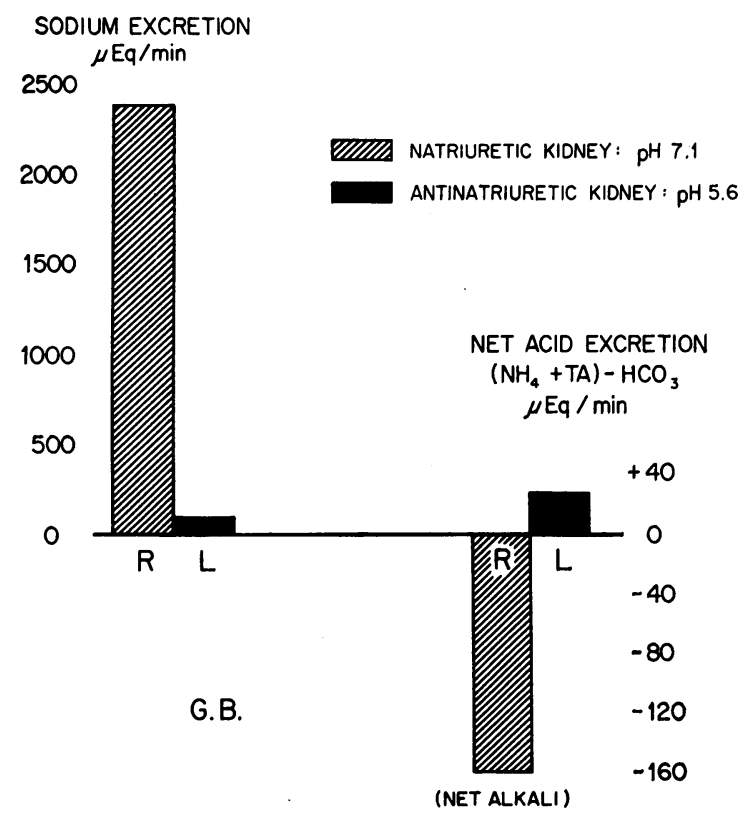

Fig. 3. Disparity IN SODIUM AND NET ACID EXCRETION BETWEEN THE TWO KIDNEYS IN PATIENT G.B. WITH STENOSIS OF LEFT RENAL ARTERY. The antinatriuresis in the affected kidney was associated with net acid excretion, whereas the contralateral kidney excreted net alkali. Urine was collected during sodium sulfate infusion.
II), whereas bicarbonate was absent from the urine of the affected kidney. Figure 3 illustrates net acid excretion in the antinatriuretic kidney and net alkali excretion in the contralateral kidney. The contralateral kidney exhibited an ex-

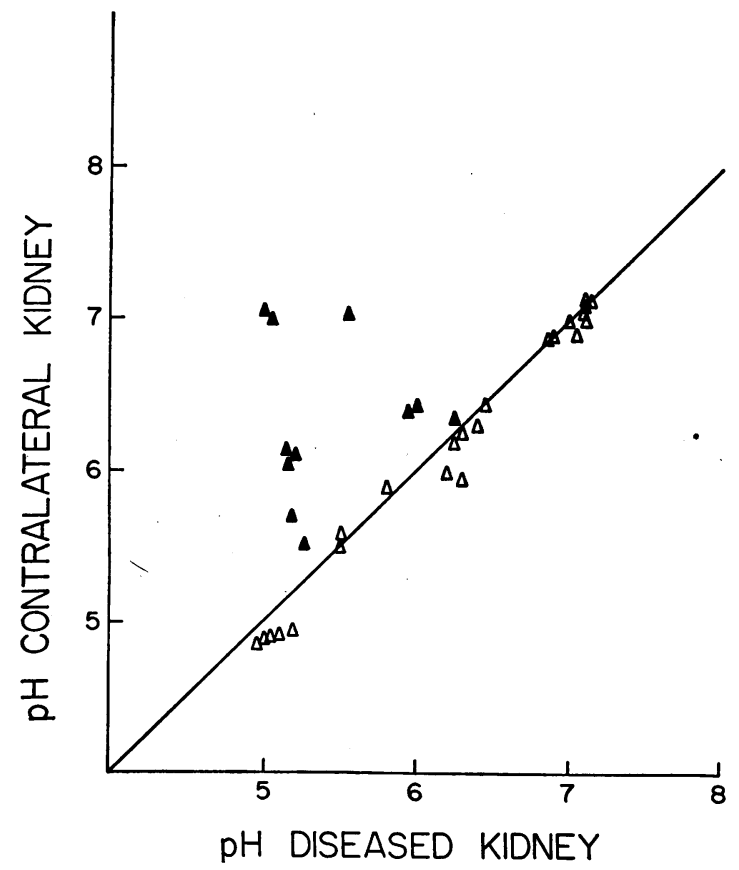

Fig. 4. Relative aciduria IN RENal arterial stenosis. Closed triangles represent comparisons between the two kidneys in unilateral arterial stenosis and open triangles in unilateral parenchymal disease. 
TABLE II

arterial stenosis and decreased excretion fraction of sodium*

\begin{tabular}{|c|c|c|c|c|c|c|c|c|c|c|c|}
\hline \multicolumn{2}{|c|}{$\mathrm{EF}_{\mathrm{Na}}$} & \multicolumn{2}{|c|}{$\mathrm{pH}$} & \multicolumn{2}{|c|}{$\mathrm{UNH}_{4} \mathrm{~V}$} & \multicolumn{2}{|c|}{$\mathrm{UNH}_{\mathrm{N}} \mathrm{V} / \mathrm{C}_{\mathrm{In}}$} & \multicolumn{2}{|c|}{ UTAV } & \multicolumn{2}{|c|}{$\mathrm{U}_{T A} \mathrm{~V} / \mathrm{C}_{\mathrm{In}}$} \\
\hline D & C & D & C & D & C & $\mathrm{D}$ & C & D & C & D & C \\
\hline \multicolumn{2}{|c|}{$\%$} & & & \multicolumn{2}{|c|}{$\mu E q / \min$} & & & \multicolumn{2}{|c|}{$\mu E q / \min$} & & \\
\hline $\begin{array}{l}0.19 \\
0.26 \\
0.38\end{array}$ & $\begin{array}{l}0.34 \\
0.41 \\
0.61\end{array}$ & $\begin{array}{l}5.3 \\
5.3 \\
5.4\end{array}$ & $\begin{array}{l}6.3 \\
6.1 \\
6.2\end{array}$ & $\begin{array}{l}8.6 \\
8.7 \\
7.8\end{array}$ & $\begin{array}{l}4.7 \\
5.5 \\
5.6\end{array}$ & $\begin{array}{l}0.21 \\
0.26 \\
0.28\end{array}$ & $\begin{array}{l}0.15 \\
0.17 \\
0.20\end{array}$ & & & & \\
\hline $\begin{array}{r}1.3 \\
5.1 \\
10\end{array}$ & $\begin{array}{l}17 \\
20 \\
23\end{array}$ & $\begin{array}{l}5.6 \\
5.0 \\
5.1\end{array}$ & $\begin{array}{l}7.1 \\
7.1 \\
7.0\end{array}$ & $\begin{array}{l}14 \\
21 \\
31\end{array}$ & $\begin{array}{l}24 \\
21 \\
25\end{array}$ & $\begin{array}{l}0.34 \\
0.50 \\
0.74\end{array}$ & $\begin{array}{l}0.24 \\
0.21 \\
0.25\end{array}$ & $\begin{array}{l}11 \\
18 \\
24\end{array}$ & $\begin{array}{l}14 \\
15 \\
21\end{array}$ & $\begin{array}{l}0.25 \\
0.43 \\
0.57\end{array}$ & $\begin{array}{l}0.14 \\
0.15 \\
0.21\end{array}$ \\
\hline $\begin{array}{l}1.4 \\
1.2 \\
1.1\end{array}$ & $\begin{array}{l}2.0 \\
2.7 \\
3.4\end{array}$ & $\begin{array}{l}6.5 \\
6.0 \\
5.9\end{array}$ & $\begin{array}{l}6.7 \\
6.9 \\
6.8\end{array}$ & $\begin{array}{l}10 \\
17 \\
15\end{array}$ & $\begin{array}{l}14 \\
21 \\
18\end{array}$ & $\begin{array}{l}0.32 \\
0.35 \\
0.38\end{array}$ & $\begin{array}{l}0.29 \\
0.32 \\
0.33\end{array}$ & $\begin{array}{l}5.7 \\
8.7\end{array}$ & $\begin{array}{l}7.1 \\
8.2\end{array}$ & $\begin{array}{l}0.18 \\
0.22\end{array}$ & $\begin{array}{l}0.15 \\
0.15\end{array}$ \\
\hline $\begin{array}{l}1.6 \\
2.3\end{array}$ & $\begin{array}{l}1.9 \\
3.1\end{array}$ & $\begin{array}{l}5.3 \\
5.2\end{array}$ & $\begin{array}{l}5.5 \\
5.7\end{array}$ & $\begin{array}{l}13 \\
12\end{array}$ & $\begin{array}{l}16 \\
14\end{array}$ & $\begin{array}{l}0.62 \\
0.57\end{array}$ & $\begin{array}{l}0.56 \\
0.56\end{array}$ & $\begin{array}{l}12 \\
11\end{array}$ & $\begin{array}{l}14 \\
11\end{array}$ & $\begin{array}{l}0.57 \\
0.53\end{array}$ & $\begin{array}{l}0.50 \\
0.46\end{array}$ \\
\hline
\end{tabular}

aggerated natriuresis in both studies of G.B. even before administration of sodium sulfate; in each instance this exaggerated natriuresis was associated with alkaluria. C.R. and M.C. had small or minimal increases in the excretion rates of ammonium and TA per unit of GFR in the kidney with renal arterial stenosis.

Potassium excretion was lower in the antinatriuretic kidney, and a slight decrease in the excretion rate was still present after correction for GFR in most of the collection periods except for one collection in G.B. at the height of sodium sulfate diuresis.

In Figure 4 urine $\mathrm{pH}$ values in the diseased kidneys are plotted against the simultaneous values in the contralateral kidneys. Open triangles represent patients with parenchymal dis- ease and closed triangles patients with renal arterial stenosis. In the patients with parenchymal disease the $\mathrm{pH}$ values were similar in the two kidneys, with the diseased kidney having a slightly more alkaline urine in a few instances. In the patients with renal arterial stenosis the urine from the affected kidney was regularly more acid than the urine from the contralateral kidney.

Control observations in patients with diffuse bilateral renal disease (group III). In Table III representative data are given for the separate kidneys of patients with symmetrical renal disease. Values for urine $\mathrm{pH}$ and ammonium excretion are shown for one patient with chronic glomerulonephritis and two patients with arteriolar nephrosclerosis. Symmetrical decreases in GFR, renal plasma flow, and salt excretion were present.

TABLE III

Urine $p H$ and excretion of ammonium in patients with varying degrees of symmetrical loss of function in the two kidneys

\begin{tabular}{|c|c|c|c|c|c|c|c|c|c|c|c|c|c|c|c|c|c|c|}
\hline \multirow[b]{2}{*}{ Patient } & \multicolumn{2}{|c|}{ V } & \multicolumn{2}{|c|}{$\mathrm{C}_{\text {In }}$} & \multicolumn{2}{|c|}{$\mathrm{C}_{\text {PAH }}$} & \multicolumn{2}{|c|}{$\mathrm{UNaV}_{\mathrm{s}}$} & \multicolumn{2}{|c|}{$\mathrm{UKV}_{\mathbf{K}}$} & \multicolumn{2}{|c|}{$\mathrm{EF}_{\mathrm{Na}}$} & \multicolumn{2}{|c|}{$\mathrm{pH}$} & \multicolumn{2}{|c|}{$\mathrm{UNH}_{\mathrm{NH}} \mathrm{V}$} & \multicolumn{2}{|c|}{$\mathrm{UNH}_{\mathbf{4}} \mathrm{V} / \mathrm{C}_{\mathrm{In}}$} \\
\hline & $\mathbf{R}$ & L & $\mathbf{R}$ & $\mathbf{L}$ & $\mathbf{R}$ & $\mathrm{L}$ & $\mathbf{R}$ & $\mathbf{L}$ & $\mathbf{R}$ & $\mathrm{L}$ & $\mathbf{R}$ & $\mathbf{L}$ & $\mathbf{R}$ & $\mathbf{L}$ & $\mathbf{R}$ & L & $\mathbf{R}$ & L \\
\hline & \multicolumn{2}{|c|}{$\mathrm{ml} / \mathrm{min}$} & \multicolumn{2}{|c|}{$m l / \min$} & \multicolumn{2}{|c|}{$\mathrm{ml} / \min$} & \multicolumn{2}{|c|}{$\mu E q / \min$} & \multicolumn{2}{|c|}{$\mu E q / \min$} & \multicolumn{2}{|c|}{$\%$} & & & \multicolumn{2}{|c|}{$\mu E q / \min$} & & \\
\hline H.E. & $\begin{array}{l}1.4 \\
1.4 \\
1.5\end{array}$ & $\begin{array}{l}1.3 \\
1.2 \\
1.4\end{array}$ & $\begin{array}{l}26 \\
23 \\
21\end{array}$ & $\begin{array}{l}30 \\
25 \\
24\end{array}$ & $\begin{array}{r}101 \\
83 \\
75\end{array}$ & $\begin{array}{r}108 \\
86 \\
94\end{array}$ & $\begin{array}{l}95 \\
92 \\
96\end{array}$ & $\begin{array}{r}99 \\
94 \\
107\end{array}$ & $\begin{array}{l}39 \\
32 \\
40\end{array}$ & $\begin{array}{l}\mathbf{4 1} \\
\mathbf{3 7} \\
\mathbf{3 4}\end{array}$ & $\begin{array}{l}2.6 \\
2.8 \\
3.2\end{array}$ & $\begin{array}{l}2.2 \\
2.6 \\
3.1\end{array}$ & $\begin{array}{l}5.7 \\
5.5 \\
5.4\end{array}$ & $\begin{array}{l}5.7 \\
5.4 \\
5.3\end{array}$ & $\begin{array}{l}3.2 \\
3.2 \\
3.3\end{array}$ & $\begin{array}{l}3.9 \\
3.6 \\
3.9\end{array}$ & $\begin{array}{l}0.12 \\
0.14 \\
0.14\end{array}$ & $\begin{array}{l}0.13 \\
0.15 \\
0.16\end{array}$ \\
\hline C.B. & $\begin{array}{l}1.0 \\
1.3 \\
1.5\end{array}$ & $\begin{array}{l}0.85 \\
1.2 \\
1.3\end{array}$ & $\begin{array}{l}21 \\
22 \\
20\end{array}$ & $\begin{array}{l}18 \\
21 \\
18\end{array}$ & $\begin{array}{l}93 \\
88 \\
68\end{array}$ & $\begin{array}{l}82 \\
86 \\
58\end{array}$ & $\begin{array}{l}108 \\
139 \\
194\end{array}$ & $\begin{array}{r}93 \\
125 \\
165\end{array}$ & $\begin{array}{l}47 \\
56 \\
62\end{array}$ & $\begin{array}{l}41 \\
54 \\
52\end{array}$ & $\begin{array}{l}3.7 \\
4.6 \\
7.2\end{array}$ & $\begin{array}{l}3.8 \\
4.3 \\
6.8\end{array}$ & $\begin{array}{l}6.8 \\
7.0 \\
7.1\end{array}$ & $\begin{array}{l}6.9 \\
7.2 \\
7.2\end{array}$ & $\begin{array}{l}3.6 \\
3.4 \\
3.6\end{array}$ & $\begin{array}{l}\mathbf{3 . 0} \\
\mathbf{3 . 2} \\
\mathbf{3 . 1}\end{array}$ & $\begin{array}{l}0.17 \\
0.15 \\
0.18\end{array}$ & $\begin{array}{l}0.17 \\
0.15 \\
0.18\end{array}$ \\
\hline R.J. & $\begin{array}{l}1.1 \\
1.1 \\
1.2\end{array}$ & $\begin{array}{l}0.98 \\
1.1 \\
1.1\end{array}$ & $\begin{array}{l}56 \\
52 \\
53\end{array}$ & $\begin{array}{l}49 \\
50 \\
50\end{array}$ & $\begin{array}{l}152 \\
141 \\
143\end{array}$ & $\begin{array}{l}136 \\
136 \\
135\end{array}$ & $\begin{array}{l}211 \\
203 \\
204\end{array}$ & $\begin{array}{l}186 \\
197 \\
193\end{array}$ & $\begin{array}{l}46 \\
44 \\
47\end{array}$ & $\begin{array}{l}41 \\
43 \\
44\end{array}$ & $\begin{array}{l}2.8 \\
2.9 \\
2.9\end{array}$ & $\begin{array}{l}2.8 \\
2.9 \\
2.9\end{array}$ & $\begin{array}{l}7.0 \\
7.0 \\
6.9\end{array}$ & $\begin{array}{l}6.8 \\
7.0 \\
7.0\end{array}$ & $\begin{array}{l}7.4 \\
6.6 \\
6.6\end{array}$ & $\begin{array}{l}6.6 \\
6.4 \\
6.5\end{array}$ & $\begin{array}{l}0.13 \\
0.13 \\
0.13\end{array}$ & $\begin{array}{l}0.13 \\
0.13 \\
0.13\end{array}$ \\
\hline
\end{tabular}


Urine $\mathrm{pH}$ and ammonium excretion were equal in the two kidneys.

\section{Discussion}

In chronic forms of renal disease (except for far advanced stages) tubular function is often decreased in proportion to the decrease in GFR, as measured by $C_{\text {In }}$. The ratio between $C_{\text {In }}$ and the maximal tubular capacity for transport of $\mathrm{PAH}$ or Diodrast remains close to normal in chronic glomerulonephritis and pyelonephritis in human as well as in experimental renal disease (13-16). Similarly the diluting capacity of the tubules, as judged from solute-free water formation, remains proportional to GFR in a wide variety of renal diseases (17-19). GFR, therefore, may be considered to provide an estimate of tubular mass or of the size of the functioning nephron population.

In the forms of human renal disease examined in our patients with unilateral involvement the excretion of ammonium was the same in the diseased as in the control kidney if expressed per unit of GFR. This proportionality between ammonium excretion and functional nephron mass was observed at different levels of ammonium excretion. Since the $\mathrm{pH}$ of the final urine was closely comparable in the diseased and the normal kidneys, we may assume that tubular fluid $\mathrm{pH}$ and hence the $\mathrm{H}^{+}$gradient determining the diffusion of ammonia into tubular fluid were similar. This would suggest that the decreased ammonium excretion by the diseased kidney is due to decreased ammonia production. The observation that this decrease was proportional to the reduction in GFR is consistent with the view that there is no limitation to ammonia production other than a decrease in the functioning nephron mass.

With the exception of two of the studies, the urine of the kidneys with parenchymal disease was acidified to the same extent as that of the control kidneys. Even after ammonium chloride loading, a similar $\mathrm{H}^{+}$gradient was reached in the two kidneys between final urine and peritubular blood. Although the $\mathrm{H}^{+}$gradient was not necessarily maximal, urine $\mathrm{pH}$ values as low as 5 were observed in the diseased kidney.

The fact that titratable acid excretion was proportional to GFR in the presence of similar urine
$\mathrm{pH}$ suggests that the availability of buffer was also a function of nephron mass. In at least four of the studies urine $\mathrm{pH}$ was sufficiently low to indicate that filtered bicarbonate was completely reabsorbed. In these studies not only net hydrogen ion excretion (estimated as the sum of ammonium and titratable acid excretion) but also total hydrogen ion secretion (estimated as bicarbonate reabsorption plus net hydrogen ion excretion) were the same per unit of GFR in the diseased and the normal kidneys. Hence, in the conditions studied, no specific tubular defect could be demonstrated for either the secretion of $\mathrm{H}^{+}$ or the formation of ammonia. This preservation of glomerulotubular balance for acid excretion in man is in accord with observations by Morrin and his associates (6) in dogs with unilateral pyelonephritis and aminonucleoside nephritis.

How glomerulotubular balance in respect to $\mathrm{H}^{+}$secretion is preserved in the diseased kidney is not well understood. According to the intact nephron hypothesis, function is lost completely in diseased nephrons and remains intact in groups of surviving nephrons. Although this hypothesis offers an attractive explanation for the preservation of glomerulotubular balance, our observations do not exclude the possibility that diseased nephrons contribute to renal function and that glomerulotubular balance is maintained by some mechanism of regulation in each nephron, whether it is diseased, atrophic, or hypertrophic.

The observed proportionality between GFR and the tubular capacity to excrete acid in these patients with pyelonephritis, renal infarction, and atrophy does not indicate that specific tubular defects may not occur in other forms of renal disease, as in renal tubular acidosis (20), hypercalcemic nephropathy $(5,21-23)$, or the kidney in gout (24).

The excretion of sodium and water was somewhat greater per unit of GFR in the diseased than in the normal kidney in six of the 11 studies (Table I). Hence, the proportionality between GFR and renal acid excretion was better than that between GFR and sodium and water excretion. In the two instances in which urine $\mathrm{pH}$ was slightly higher in the diseased kidney, acid excretion was nevertheless proportional to GFR. A slight sodium diuresis per unit of GFR has also been observed by Morrin, Gedney, New- 
mark, and Bricker (25) in the experimentally diseased kidney. In their observations in the dog, increased excretion fractions of sodium were associated with slight increases in bicarbonate excretion in the diseased kidney but not with significant changes in ammonium and TA excretion per unit of GFR.

Although renal acid excretion was determined primarily by the size of the functioning nephron population and urine $\mathrm{pH}$ was similar in the two kidneys in unilateral parenchymal disease, in our patients with renal arterial stenosis the urine was acidified to a greater extent in the affected kidneys than in the contralateral kidneys. Similar aciduria in renal arterial stenosis has been observed in case reports by Gowenlock and Wrong (8) and Yendt, Kerr, Wilson, and Jaworski (7).

In the present study, subject G.B., who had the greatest disparity in the excreted fraction of sodium between the two kidneys, also had the greatest disparity in urine $\mathrm{pH}$. In this subject ammonium and titratable acid excretion were increased per unit of GFR in the affected kidney. Because of the bicarbonate diuresis in the contralateral kidney, the disparity in net acid excretion was considerably greater than that in the sum of ammonium and TA excretion. In the other cases smaller increases in the excretion of ammonium and TA per unit of GFR were observed. The significance of these increases depends on the validity of using GFR as a measure of nephron mass in renal arterial stenosis. It is possible in this condition that filtration rate per nephron is decreased and that the excretion of ammonium and TA per nephron mass is unchanged.

The consistently lower urine $\mathrm{pH}$ in the affected kidney might be attributed to increased secretion of hydrogen ions in exchange for reabsorbed sodium or to a greater fractional reabsorption of anions that may buffer hydrogen ions.

Whatever the mechanism of aciduria may be, these observations in patients with renal arterial stenosis appear to modify the general relationship noted in unilateral parenchymal disease of the kidney between GFR and acidifying capacity.

\section{Summary}

The excretion of acid by the diseased kidney was studied in unilateral renal disease in man by comparing the diseased kidney with the "nor- mal" or less affected kidney. Eight patients with parenchymal disease and four with stenosis of the main renal artery were examined.

In the patients with parenchymal renal disease (pyelonephritis, infarction, atrophy) the excretion of ammonium and titratable acid in the diseased kidney was decreased in proportion to the decrease in functioning nephron mass as estimated from glomerular filtration rate (GFR). Even after ammonium chloride loading, urine $\mathrm{pH}$ and ammonium and titratable acid excretion per unit of GFR remained similar in the diseased and normal kidneys. Hence, in the diseases studied no specific tubular defect could be demonstrated for either the secretion of hydrogen ions or the production of ammonia.

The proportionality between GFR and the tubular capacity to excrete acid observed in unilateral parenchymal disease was modified in the four patients with unilateral renal arterial stenosis in whom the urine from the affected kidney was acidified to a greater extent than that from the contralateral kidney

\section{Appendix}

Patients listed in Table I

C.C. Atrophy of left kidney. A 42-year-old Negro man with a 2-year history of hypertension. Blood pressure, 170/120. Grade I hypertensive retinopathy. Urinalysis normal and urine culture sterile. Chest $\mathrm{X}$ ray and ECG normal. Intravenous pyelography revealed a shrunken left kidney with crowding of the calyceal system and a normal right kidney. Aortography demonstrated a small left renal artery without evidence of obstruction. Biopsy of the left kidney revealed arteriosclerosis of the small arteries and arterioles; ten of 22 glomeruli in the specimen were completely hyalinized; interspersed with these were glomeruli that appeared normal.

I.M. Infarction of upper pole of left kidney. A 46year-old white woman with a 1-year history of hypertension. Blood pressure, 170/110. Eyegrounds, chest $\mathrm{X}$ ray, and ECG normal. Urinalysis normal except for trace proteinuria. Intravenous pyelography revealed that the upper pole of the left kidney was contracted. Aortography revealed changes consistent with fibromuscular hyperplasia in the superior mesenteric artery. The main renal arteries were patent. The upper pole of the left kidney was markedly contracted and supplied by a very narrow aberrant artery.

R.L. Right hypoplastic kidney. A 39-year-old white man with a 4-year history of hypertension. Blood pressure, 165/115. Eyegrounds, chest X ray, ECG, and urinalysis normal. Intravenous pyelography revealed the 
right kidney to be in the pelvis and slightly smaller than the left kidney. Both main renal arteries were patent on aortography.

H.R. Pyelonephritis of right kidney. A 43-year-old Puerto Rican woman with a 5-year history of hypertension. History of pyuria at age 28 and urinary tract infection with $E$. coli at age 41. Blood pressure, 210/120. Grade II hypertensive retinopathy. Enlarged heart by chest $\mathrm{X}$ ray and left ventricular hypertrophy by ECG. Urinalysis revealed minimal proteinuria and 2 to 4 leukocytes in the sediment. Intravenous pyelography revealed blunting of the calyces on the right and a normal calyceal system on the left.

T.A. Left hypoplastic kidney. A 46-year-old Negro woman with a 1-year history of hypertension. Blood pressure, 180/110. Grade III hypertensive retinopathy. Urinalysis demonstrated that the left kidney was located in the pelvis and the collecting system was smaller than that of the right kidney, which was in normal position. Aortography revealed that the left renal artery arose from the common iliac artery.

C.S. Pyelonephritis of the right kidney. A 20-yearold Negro man with a 7-year history of hypertension, proteinuria, and recurrent urinary tract infection. Blood pressure, 180/125. Grade III hypertensive retinopathy. Slight cardiomegaly. The urine contained 1 to $2+$ protein and occasional leukocytes. Urine culture revealed $\dot{E}$. coli. Intravenous pyelogram showed clubbing of the calyces on the right. Aortography and selective renal angiography revealed normal renal arteries; the interlobar and interlobular arteries of the right kidney appeared crowded in several areas. The functional pattern presented in Table I was observed on three different occasions.

M.J. Pyelonephritis of the right kidney. A 33-yearold Negro woman with a 6-year history of hypertension first noted during her fourth pregnancy, which was complicated by a urinary tract infection. Blood pressure, 170/110. Grade I hypertensive retinopathy. Chest $\mathrm{X}$ ray and ECG normal. Urinalysis normal except for trace proteinuria. Intravenous pyelogram showed a contracted right kidney with crowding and clubbing of the calyces and a normal left kidney.

M.P. Atrophy of left kidney, probably secondary to pyelonephritis. A 44-year-old Negro woman with an 8-year history of hypertension. Blood pressure, 180/120. Grade II hypertensive retinopathy with retinal vein thrombosis in the left eye. Chest $\mathrm{X}$ ray normal. ECG revealed nonspecific $\mathrm{T}$-wave changes. Urinalysis normal. Intravenous pyelogram revealed a small left kidney with blunting of the calyces and marked thinning of the cortex in the upper pole. The right kidney appeared normal. Retrograde femoral arteriography revealed evidence of atherosclerosis in the aorta and left renal artery without significant stenosis.

\section{Patients listed in Table II}

H.J. Atherosclerosis; stenosis of left renal artery. A 50 -year-old Negro man with a 20 -year history of hyper- tension. Arterial insufficiency of left leg led to amputation 20 years ago. Blood pressure, 230/140. Grade I hypertensive retinopathy. Urinalysis and chest $\mathrm{X}$ ray normal. ECG revealed changes consistent with left ventricular hypertrophy. Intravenous pyelogram normal. Aortography revealed extensive atheromatous disease involving the aorta, the iliac arteries, and both renal arteries with numerous small plaques and a larger plaque in the left renal artery.

G.B. Fibromuscular hyperplasia; stenosis of left renal artery. A 34-year-old Negro woman with an 8-year history of hypertension. Blood pressure, 200/130. Grade II hypertensive retinopathy. No bruit. Urinalysis revealed $1+$ proteinuria. Urine culture sterile. Intravenous pyelography showed delayed visualization of the left kidney. Aortography showed marked narrowing of the left main renal artery with collateral vessels supplying the hilum and changes consistent with fibromuscular hyperplasia in the common hepatic artery. After the observations presented in Table II a splenorenal anastomosis was performed. Biopsy of the left kidney showed tubular atrophy. The shunt functioned well 1 month after operation as judged from selective arteriography of the celiac axis. GFR and renal plasma flow failed to increase after surgery and subsequently decreased further. Hypertension persisted. Left nephrectomy was performed 5 months after the shunt operation. Blood pressure, 155/100 6 months after nephrectomy.

C.R. Atherosclerosis; stenosis of left renal artery. A 33-year-old white woman with a 10-year history of hypertension. Blood pressure 240/150. Grade III hypertensive retinopathy. Urinalysis normal. Chest $\mathrm{X}$ ray showed cardiomegaly. ECG revealed changes consistent with left ventricular hypertrophy. Intravenous pyelography revealed a normal calyceal system bilaterally. Aortography demonstrated stenosis at the origin of the left renal artery. At operation an atherosclerotic plaque was found in the left renal artery. Hypertension persisted 4 months after nephrectomy.

M.C. Atherosclerosis; stenosis of right renal artery. A 54-year-old white woman with a 5-year history of hypertension. Blood pressure, 170/120. Grade II hypertensive retinopathy. Urinalysis normal; urine culture sterile. Chest $\mathrm{X}$ ray revealed slight cardiomegaly, and ECG was consistent with left ventricular hypertrophy. Intravenous pyelogram normal. Aortography showed a plaque narrowing the right renal artery near the origin.

\section{Patients listed in Table III}

H.E. Chronic glomerulonephritis. A 26-year-old Philippino man with a 5-year history of hypertension and proteinuria. Blood pressure, 155/102. Grade I hypertensive retinopathy. Urine showed persistent proteinuria and occasional erythrocytes. Chest $\mathrm{X}$ ray, intravenous pyelogram, and aortogram normal. Renal biopsy consistent with chronic glomerulonephritis.

C.B. Essential hypertension, nephrosclerosis. A 44 year-old Negro man with a 4-year history of hypertension discovered because of an episode of left ventricular 
failure. Blood pressure, 190/130. Grade II hypertensive retinopathy. The heart was enlarged on roentgenogram of the chest, and the ECG was consistent with left ventricular hypertrophy. Proteinuria varied from trace to $2+$, but urine sediment was negative and culture was sterile. Intravenous pyelogram and aortogram were normal, and percutaneous renal biopsy demonstrated only the changes of arteriolar nephrosclerosis.

R.J. Essential hypertension, nephrosclerosis. A 42year-old Negro man with a 13-year history of hypertension. Blood pressure, 210/150. Grade III hypertensive retinopathy. Cardiomegaly was noted on chest $\mathrm{X}$ ray, and the ECG revealed left ventricular hypertrophy. The urine contained $1+$ protein and 10 to 12 erythrocytes per high power field. Intravenous pyelogram and retrograde femoral aortogram were normal. Renal biopsy demonstrated arteriolar nephrosclerosis.

\section{Acknowledgments}

We are grateful to Misses J. Tonnesen, N. Burton, S. Fox, F. Reff, and E. McIntosh for technical assistance.

\section{References}

1. Palmer, W. W., and L. J. Henderson. A study of the several factors of acid excretion in nephritis. Arch. intern. Med. 1915, 16, 109.

2. Van Slyke, D. D., G. C. Linder, A. Hiller, L. Leiter, and J. F. McIntosh. The excretion of ammonia and titratable acid in nephritis. J. clin. Invest. 1926, 2, 255.

3. Schwartz, W. B., and A. S. Relman. Acidosis in renal disease. New Engl. J. Med. 1957, 256, 1183.

4. Schwartz, W. B., P. W. Hall III, R. M. Hays, and A. S. Relman. On the mechanism of acidosis in chronic renal disease. J. clin. Invest. 1959, 38, 39.

5. Wrong, O., and H. E. F. Davies. The excretion of acid in renal disease. Quart. J. Med. 1959, 28, 259.

6. Morrin, P. A. F., N. S. Bricker, S. W. Kime, Jr., and $\mathrm{C}$. Klein. Observations on the acidifying capacity of the experimentally diseased kidney in the dog. J. clin. Invest. 1962, 41, 1297.

7. Yendt, E. R., W. K. Kerr, D. R. Wilson, and Z. F. Jaworski. The diagnosis and treatment of renal hypertension. Amer. J. Med. 1960, 28, 169.

8. Gowenlock, A. H., and O. Wrong. Hyperaldosteronism to renal ischaemia. Quart. J. Med. 1962, 31, 323.

9. Kjellbo, H., P. Vikgren, S. Oman, and B. Hood. The functional pattern of renal artery stenosis. Acta med. scand. 1962, 172, 485.

10. Hulet, W. H., C. W. Hagedorn, J. R. Richardson, Jr., and B. J. Hartley. Communication, Proceedings of the Second International Congress of Nephrology. Basel, S. Karger, 1964, in press.
11. Hulet, W. H., D. S. Baldwin, A. W. Biggs, E. A. Gombos, and $H$. Chasis. Renal function in the separate kidneys of man. I. Hemodynamics and excretion of solute and water in normal subjects. J. clin. Invest. 1960, 39, 389.

12. Steinmetz, P. R., and N. Bank. Effects of acute increases in the excretion of solute and water on renal acid excretion in man. J. clin. Invest. 1963, 42, 1142.

13. Smith, H. W. The Kidney: Structure and Function in Health and Disease. New York, Oxford, 1951, p. 836.

14. Michie, A. J., and C. R. Michie. Kidney function in unilateral pyelonephritis. I. Clinical data. Amer. J. Med. 1957, 22, 179.

15. Michie, A. J., C. R. Michie, and M. C. Ragni. Kidney function in unilateral pyelonephritis. II. Physiologic interpretations. Amer. J. Med. 1957, 22, 190.

16. Bricker, N. S. Chronic progressive renal disease; pathologic physiology and relation to treatment. Progr. cardiovasc. Dis. 1961, 4, 170.

17. Bricker, N. S., R. R. Dewey, H. Lubowitz, J. Stokes, and $\mathrm{T}$. Kirkensgaard. Observations on the concentrating and diluting mechanisms of the diseased kidney. J. clin. Invest. 1959, 38, 516.

18. Kleeman, C. R., D. A. Adams, and M. H. Maxwell. An evaluation of maximal water diuresis in chronic renal disease. I. Normal solute intake. J. Lab. clin. Med. 1961, 58, 169.

19. Steinmetz, P. R., R. P. Eisinger, E. A. Gombos, H. Chasis, and D. S. Baldwin. Excretion of free water and solute during maximal water diuresis in normal and hypertensive subjects. J. Lab. clin. Med. 1964, 64, 238.

20. Elkinton, J. R., E. J. Huth, G. D. Webster, and R. A. McCance. The renal excretion of hydrogen ion in renal tubular acidosis. I. Quantitative assessment of the response to ammonium chloride as an acid load. Amer. J. Med. 1960, 29, 554.

21. Fourman, P., B. McCankey, and J. W. G. Smith. Defects of water reabsorption and of hydrogen ion excretion by the renal tubules in hyperparathyroidism. Lancet 1960, 1, 619.

22. Ferris, T. F., H. Levitin, E. T. Phillips, and F. H. Epstein. Renal potassium-wasting induced by vitamin D. J. clin. Invest. 1962, 41, 1222.

23. Heinemann, H. O. Reversible defect in renal ammonium excretion in patients with hypercalcemia. Metabolism 1963, 12, 792.

24. Gutman, A. B., and T. F. Yu. An abnormality of glutamine metabolism in primary gout. Amer. J. Med: 1963, 35, 820 .

25. Morrin, P. A. F., W. B. Gedney, L. N. Newmark, and N. S. Bricker. Bicarbonate reabsorption in the dog with experimental renal disease. J. clin. Invest. 1962. 41, 1303. 